\title{
脳内幹細胞・前駆細胞のイメージング及び操作技術が解き明かす脳組織の新しい機能維持機構
}

\author{
片岡洋祐 $a, b$
}

\section{Imaging and Manipulation of Stem and Progenitor Cells for Revealing the Novel Mechanism of Local Tissue Maintenance in the Brain}

\author{
Yosky Kataoka ${ }^{a, b}$ \\ ${ }^{a}$ Laboratory for Cellular Function Imaging, RIKEN Biosystems Dynamics Research; 6-7-3 Minatojima-minamimachi, \\ Chuo-ku, Kobe 650-0047, Japan: and ${ }^{b}$ Multi-modal Microstructure Analysis Unit, RIKEN-JEOL Collaboration \\ Center; 6-7-3 Minatojima-minamimachi, Chuo-ku, Kobe 650-0047, Japan.
}

(Received August 27, 2020)

\begin{abstract}
We have been investigating the physiological and pathological roles of stem cells and progenitor cells in the central nervous system using multimodal imaging methods, including positron emission tomography (PET), in vivo optical imaging, and light as well as electron microscopy. Furthermore, we generated transgenic rats for selective ablation of these cells. Imaging studies have demonstrated the proliferation and dynamics of neural stem cells in neurogenic regions and glial progenitor cells expressing a chondroitin sulfate proteoglycan (neuron-glial antigen 2; NG2) in the brain of adult rodents. Glial progenitor cells change their direction of differentiation into mature oligodendrocytes or astrocytes by neural activity following their proliferation. This phenomenon was thought to control the local tissue structure for maintenance of moderate neural activity. Furthermore, selective ablation of glial progenitor cells in the brain induced defects of neurons via neuroinflammation with microglial activation and proinflammatory cytokine production in the region. Thus, we have proposed a novel concept that glial progenitor cells regulate the neuro-immune system in the central nervous system, in addition to their role as germinal cells, giving rise to mature glial cells. Neuroinflammation is associated with the onset and progression of depression, chronic fatigue syndrome, and neurodegenerative diseases, including Alzheimer's disease. Anti-inflammatory effects of glial progenitor cells might bring about the possibility of these cells as the new therapeutic targets for such neurological disorders.
\end{abstract}

Key words—— neural stem cell; glial progenitor cell; microglia; neuroinflammation; imaging

\section{はじめに}

中枢神経では海馬歯状回や側脳室周囲において, 一生にわたって神経新生が継続している. ${ }^{1-3)}$ ま た，こうした神経新生領域以外でも，グリア系前駆 細胞が恒常的な細胞新生に与っており，細胞を供給

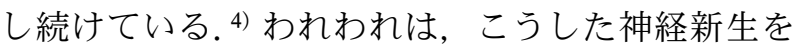
げっ歯類を用いて非侵襲的にイメージングする技術 を開発してきた．例えば，海馬歯状回や側脳室周囲 における細胞増殖活性を陽電子放射断層撮影法 (positron emission tomography; PET) を用いてイ

$a$ 理化学研究所生命機能科学研究センター細胞機能評価 研究チーム (T650-0047 神戸市中央区港島南町 6-7-3), $b$ 理研-JEOL 連携センターマルチモダル微細構造解析 連携ユニット（テ650-0047 神戸市中央区港島南町 6-73) e-mail: kataokay@ riken.jp 本総説は, 日本薬学会第 140 年会シンポジウムS10 で 発表した内容を中心に記述したものである.
メージングすることに成功し，神経新生能が抑うつ 状態などに反応することを可視化した. ${ }^{5)}$ 一方，グ リア系前駆細胞については，イメージング技術のみ ならず, 細胞特異的に生体から除去できる操作技術 を確立し，その新しい生理機能について研究を行つ てきた. ${ }^{6}$ 特に，グリア系前駆細胞の多くがニュー ロン細胞体に密着して存在することから, 7) われわ れは, 前駆細胞が単に細胞供給に与るだけでなく, ニューロンに対する機能調節や機能保全を担当す る，いわばナーシング細胞としての役割を担ってい るとの仮説を提唱してきた．特に，グリア前駆細胞 のみを人工的に脱落させたところ, 周囲組織のミク ログリアの活性化と炎症性サイトカイン産生による 神経炎症病態が惹起され，海馬ではニューロンが変 性脱落することがわかつた，さらに，前駆細胞を脱 落させた組織でも神経炎症を薬理学的に抑制すると ニューロンは生存し続けたことから，中枢神経組織 
におけるグリア前駆細胞は免疫応答の制御を通して 神経機能維持にも与っていることが示された。 ま た，長期にわたつて特定の細胞の動態を追跡できる 遺伝子改変動物を作出することで，中枢神経系以外 の様々な臓器にもグリア前駆細胞と機能上共通点の 多い細胞が存在することもわかってきている. ${ }^{8)}$ 本 稿では特に中枢神経グリア前駆細胞の新しいはたら きに注目し，局所脳組織の機能維持・制御の観点か ら議論する.

\section{脳内の細胞増殖}

哺乳類の中枢神経系においても成熟してなお恒常 的に細胞増殖が観察される．特に，海馬歯状回や側 脳室周囲の限られた領域では, 神経新生が継続して 観察される.1,2) こうした現象は，ヒトにおいても観 察され, ${ }^{3)}$ 神経機能とも深く係わっていることが報 告されてきた。例えば，海馬における神経新生は学 習機能や, 9,10)うつ病との関係も報告されてい

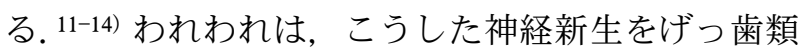
を対象に非侵襲的にイメージングする技術を開発し てきた，例えば，海馬歯状回や側脳室周囲における 細胞増殖活性をPET を用いてイメージングし，海 馬歯状回での神経新生が抑うつ状態では低下し，抗 うつ薬投与によって回復する様子を動物が生きた状

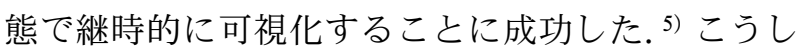
たイメージング技術は，同じ動物に対して継続的に 何度も神経新生能を定量することができるため，様 々な食薬の効果判定や加齢による変化を評価する上 で大きな武器となる。

一方，こうした神経新生領域以外の場所でも細胞 増殖や細胞の入れ替わりが起こっていることが知ら れている，例えば細胞周期の DNA 合成時に利用さ れるトリチウムチミジンを投与し，動物屠殺後にミ クロオートラジオグラフィー法を施すことで，増殖 中の細胞を組織学的に捉え，さらに細胞の入れ替わ り(ターンオーバー)を調べることができる. 特に, 数十日から数百日かけたゆっくりとした細胞の入れ 替わりについても，トリチウムチミジンの投与法を 工夫することで，その細胞動態を理解することがで

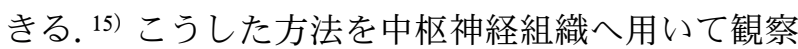
したところ，神経新生領域以外においても，脳内で 細胞が 1 年くらいかけてゆっくりと新しい細胞に入 れ替わっていること，そして，こうした細胞は主に グリア細胞であることもわかっている. ${ }^{4)}$ 近年，こ
うしたグリア細胞の入れ替わりを維持する前駆細胞 の存在が詳細に研究され，オリゴデンドロサイト， アストロサイト，ミクログリアに続き，第 4 のグリ アとしてその機能が広く知られるようになった。

\section{グリア前駆細胞の増殖と分化}

哺乳類において，グリア前駆細胞は中枢神経系全 般に分布し，生理条件下においても増殖活性を維持 しており，増殖細胞マーカーである Ki67 の発現細 胞，あるいはチミジンのアナログであるブロモデオ キシウリディン (BrdU) の取り込み細胞として観 察される (Fig. 1). ${ }^{7,16)}$ 本細胞が個体発生期から一 生涯にわたってオリゴデンドロサイトを生み出し続 けるため, oligodendrocyte precursor cell (OPC) とも呼ばれてきた. ${ }^{17)}$ われわれが主な観察対象とし てきた大脳皮質では，多くのグリア前駆細胞が神経 細胞体に密着して存在している，さらに，増殖分裂 後には，その娘細胞の 70-80\%は前駆細胞のまま神 経細胞体付近に留まる一方，残りの細胞は成熟グリ ア細胞に分化しながら神経細胞体から離れていくこ とも観察されており，神経細胞体周囲が一種の細胞 増殖ニッチを形成しているものと考えられる。 ${ }^{71}$ ま た，グリア前駆細胞は，核内に glutathione $S$-transferase Pi $(\mathrm{GST} \pi)$, 細胞質に neuron-glial antigen 2 (NG2) や platelet-derived growth factor receptor $\alpha$ $(\operatorname{PDGFR} \alpha)$, Doublecortin などを発現しており, ${ }^{18)}$ 特に NG2 や PDGFR $\alpha$ はグリア前駆細胞のマー カーとしてよく使用されている。こうした背景か ら，グリア前駆細胞は，NG2 グリアとも呼ばれ る。さらに，前駆細胞が分化しながら神経細胞体か ら離れていく過程で，こうしたマーカー分子の発現 は徐々に低下し，逆に分化細胞特有の分子の発現が 上昇する. ${ }^{19)}$

グリア前駆細胞はオリゴデンドロサイトを産生す ることで，中枢神経機能維持に与っていることは疑 いようがないが，近年，本細胞がオリゴデンドロサ

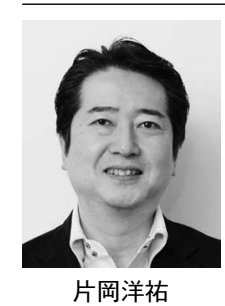

1965 年 5 月 5 日京都生まれ。滋賀医科 大学医学部卒業後, 京都大学大学院に て医学博士を取得. 大阪バイオサイエ ンス研究所神経科学部門・研究員, 関 西医科大学解剖学及び大阪市立大学大 学院医学研究科システム神経科学・講 師を経て 2009 年より理化学研究所・ チームリーダー. 岡山大学大学院医歯 薬学総合研究科・客員教授. 

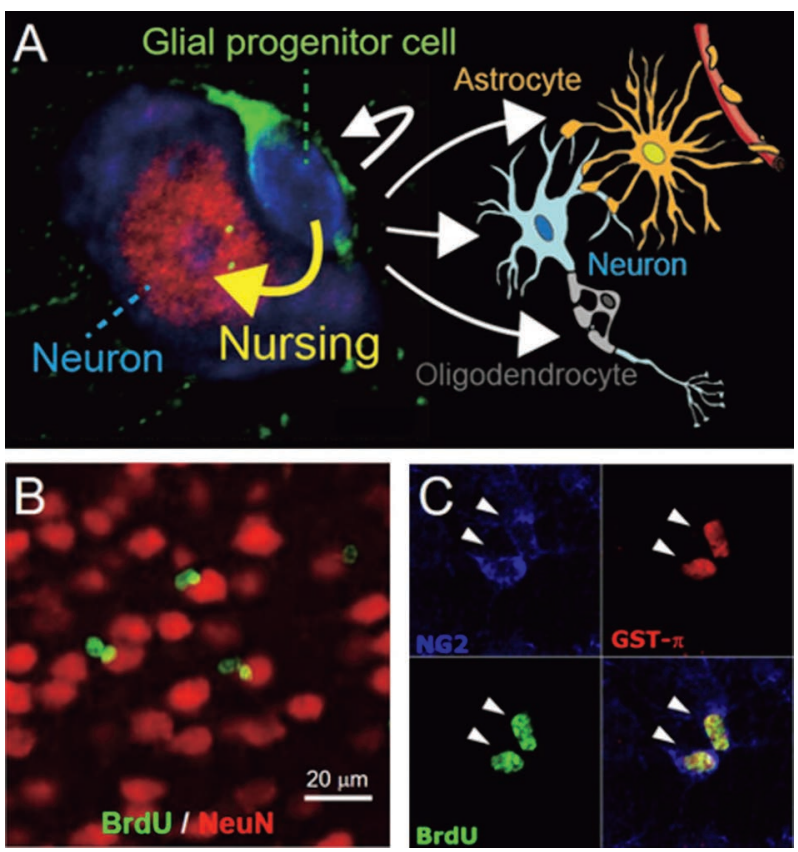

Fig. 1. Proliferation and Differentiation of Glial Progenitor Cells

(A) Schema of a glial progenitor cell attached to a neuron, and differentiation of progenitor cells into oligodendrocytes, astrocytes, neurons, and self-renewal. "Nursing" indicates the concept of glial progenitor cell to maintain the neuronal environment. (B) Confocal laser microscopic view of 5-bromo-2-deoxyuridine (BrdU)-incorporated nuclei (green) in glial progenitor cells and NeuN-immunopositive neurons (red) in the rat cerebral cortex. Glial progenitor cells are shown as twin daughter cells following mitoses near neuronal somata. (C) Triple immunohistochemical staining for NG2 (blue in the cytoplasm) and GST-p (red in the nuclei), and BrdU (green in the nuclei) in proliferating glial progenitor cells (arrowheads). Right bottom corner, merged view.

イトに加え，アストロサイトやニューロンにも分化 できる多分解能を有しているものと考えられている [Fig. 1(A)]. 18,20-22) われわれは，ラット大脳皮質へ の広範な脱分極刺激（Spreading depression）が, グリア前駆細胞の増殖活性や各グリア細胞への分化 方向を変化させることを見い出した．特に，脱分極 刺激の回数に依存してグリア前駆細胞が増殖を活発 化させること，さらに，増殖した細胞の一部がアス トロサイトへも分化し始めることを報告した. ${ }^{20)}$ オ リゴデンドロサイトは神経細胞軸索における活動電 位の伝搬速度や活動度を調整するが，過剩な神経興 奮が与えられた脳内領域では新たにアストロサイト の産生が充進することで, 興奮性神経伝達物質であ るグルタミン酸の回収能力を増強して神経興奮に対 する耐性を強化し，神経情報処理機構を安定的に維 持するとの仮説が想定できる，つまり，グリア前駆 細胞はニューロンの活動を常にモニターし，増殖と 分化，そして分布先を調節することで中枢神経組織
の興奮度を調整する，いわば「細胞構築の可塑性」 を担う能力を内包しているものと考えられる（Fig. 2). 加えて，グリア前駆細胞がニューロンからのシ ナプス入力を受けているとの報告もあり, ${ }^{23,24)}$ 前駆 細胞が単に新しい細胞を生み出すだけでなく，神 経ーグリア間の機能連関を構成，維持する担い手の 1つであると考えられる.

\section{グリア前駆細胞による神経炎症制御}

グリア前駆細胞の増殖と分化による中枢神経機能 維持について述べてきた。 また，前駆細胞が神経細 胞体など，ニューロンと密着して存在することか ら，神経機能とグリア前駆細胞との間にはなんらか の重要な機能連関があるものと想像される。そこ で，われわれは成熟したラットの脳内でグリア前駆 細胞のみを選択的に除去することで，当細胞の新た な機能を探ることに挑戦した。本実験において，グ リア前駆細胞が発現する分子である NG2 のプロ モーターの下流領域に単純ヘルペスウィルス 1 型チ ミジンキナーゼ (herpes simplex virus 1-thymidine kinase；HSVtk）を組み込んだ遺伝子改変ラットを 作出し，NG2 を発現する細胞に HSVtk を発現させ

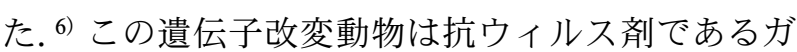
ンシクロビルを投与することで, HSVtk を発現す るグリア前駆細胞のみを, 分裂・増殖時に特異的に 死滅させることができる，実際，遺伝子改変動物の 脳室内にガンシクロビルを持続投与したところ，グ リア前駆細胞のみが脳室周辺領域（中隔, 線条体, 視床，海馬など）において，投与 1 日後から消失し 始め，2-3 日後にはほとんどすべて除去された。 そ して, グリア前駆細胞の選択的除去後には, 周辺領 域で多数のミクログリアが活性化し，さらに炎症性 サイトカイン（IL-1 $\beta, \mathrm{TNF} \alpha, \mathrm{IL}-6)$ の発現上昇が 引き起こされることが見い出された. さらに，こう した神経炎症が惹起された脳領域では, 数日で神経 細胞が変性し, 特に海馬ではほとんどのニューロン が細胞死に陥ることもわかつた。 なお，IL-1 $\beta$ の作 用を抑制する IL-1 受容体アンタゴニストの脳室内 投与，あるいはミクログリア活性化の選択的阻害剂 であるミノサイクリンの投与によって，神経細胞は 変性・細胞死から免れることもわかつた。こうした 研究結果から，グリア前駆細胞を選択的に除去する と，その領域でミクログリアが活性化して炎症性サ イトカインを産生すること，さらにこうした神経炎 


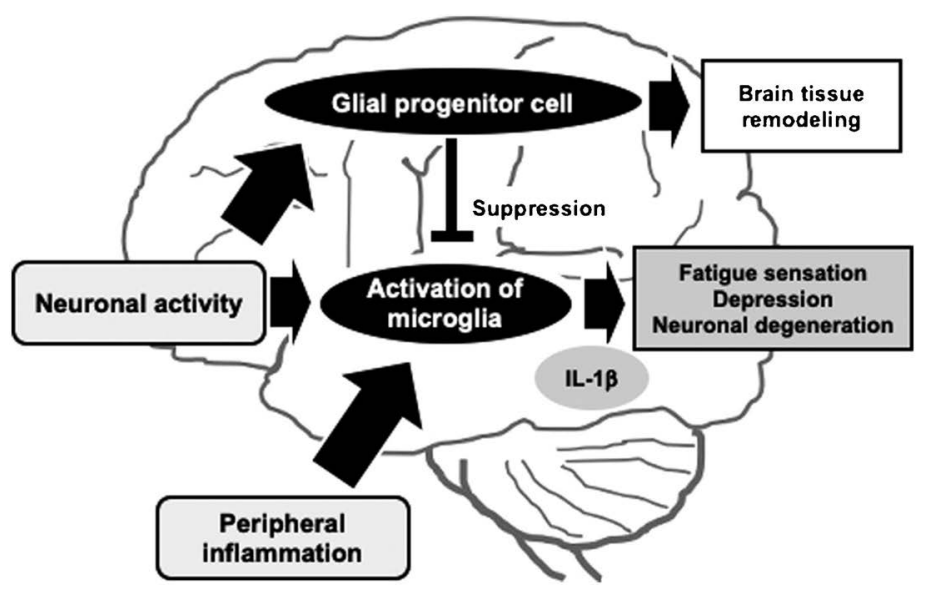

Fig. 2. Schematic Drawing of Novel Roles of Glial Progenitor Cells in the Brain

Neuronal activity or peripheral inflammation induces activation of microglia and production of proinflammatory cytokines including IL- $1 \beta$ (neuroinflammation) which trigger fatigue sensation, depression, and/or neuronal degeneration etc. Glial progenitor cells control the neuro-immune system. Further, glial progenitor cells proliferate and differentiate into astrocytes as well as oligodendrocytes depending on neuronal activity and bring about local tissue remodeling for maintaining stable neuronal activity.

症が引き金となり，神経細胞が変性・脱落すること が示された。つまり，成熟脳においてグリア前駆細 胞はミクログリアの活性化（神経炎症）を抑制する ことで免疫応答を制御し，神経機能の保持に深く寄 与していることが明らかとなった（Fig. 2).

こうしたグリア前駆細胞の除去手法は他の研究グ ループでも利用されており，グリア前駆細胞の神経 炎症以外の新規機能についても報告されている.

Birey らは，グリア前駆細胞の選択的除去がアスト ロサイトによるグルタミン酸再取り込み活性の阻害 を誘発し，興奮性神経伝達の抑制及びうつ様行動を 引き起こすことを報告している. ${ }^{25)}$ また, Djogo ら は，グリア前駆細胞がレプチン受容神経の樹状突起 の構造維持に関与し，摂食抑制行動の調節を担って いる可能性を示している. ${ }^{26)}$ 今後も，細胞特異的な イメージングや選択的除去技術は, 組織中での細胞 の新しい役割を研究する上で大いに役立つものと思 われる。

\section{神経炎症と神経疾患}

疾患モデル動物やヒトを対象としたイメージング 技術の発展により，アルツハイマー病などの神経変 性疾患や，うつ病・統合失調症などの精神疾患の発 症・進展が神経炎症と深く係わることがわかってき ている，われわれも神経炎症に係わる活性化ミクロ グリア及びアストロサイトの PET イメージング法 を用いて，片頭痛モデル動物や慢性疲労症候群患者 での脳内神経炎症を可視化してきた。片頭痛モデル
は，ラットの大脳皮質へ上述した脱分極波を惹起す ることで作製した。 その後, 活性化ミクログリアが 発現する分子に親和性のある PET リガンドの 1 つ $\left[{ }^{11} \mathrm{C}\right] \mathrm{PK} 11195$ を投与して神経炎症領域を可視化す ることに成功した. ${ }^{27)}$ その結果，脱分極波が伝搬し た片側大脳皮質に高い集積像が得られ，片頭痛発作 後, 数日にわたつて神経炎症が引き起こされること が示された，さらに，片頭痛モデル動物の痛み伝達 神経系をPET で可視化することもできた。 ${ }^{28)}$ 一 方，慢性疲労症候群患者でも同様に $\left[{ }^{11} \mathrm{C}\right] \mathrm{PK} 11195$ を用いた脳内ミクログリアの活性化を調べた。そし て，患者の脳内では神経炎症が広い領域で観察され ることや，慢性疲労症候群の症状である認知機能低 下やうつ症状, 痛夕感覚の増幅と, 神経炎症の程度 （PET シグナルの強度）がよく相関する脳内領域 （扁桃体・海馬・視床）も明らかとなった. ${ }^{29)}$ なお, 実験動物を用いた研究では，ミクログリアの活性化 は炎症性サイトカイン, 特に IL- $1 \beta$ を産生すること により動物の行動を強く抑制すること, ${ }^{30)}$ このメカ ニズムにアストロサイトからのインターフェロン放 出とそれによるセロトニン神経機能の低下が係わつ ているものと考えられている. ${ }^{31)}$

このように，神経炎症は種々の中枢神経疾患にお ける基盤病態であり, 神経炎症制御機構の解明がこ れら中枢神経疾患の新たな治療法開発の鍵となるも のと考えられる，これまでの研究から，神経炎症が ミクログリアの活性化によって惹起されること, ${ }^{32)}$ 
さらに，活性化ミクログリアが種々の炎症性サイト カインの産生・分泌を介して, 反応性アストロサイ トの活性化を誘発し，神経炎症の増悪を引き起こす

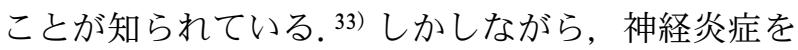
緩和又は制御する細胞についての知見は，これまで ほとんどなかった。本稿では，第4 のグリアである グリア前駆細胞がミクログリアの活性化を抑制する ことで神経炎症を制御し，神経機能保持を担ってい ることを紹介した。こうした成果は，今後，グリア 前駆細胞が神経炎症と係わる様々な神経疾患の新た な治療ターゲットとなる可能性を示唆している.

おわりに

中枢神経組織では一部のニューロンとグリア細胞 が一生にわたって増殖能を維持し, 細胞のターン オーバーを繰り返している。こうした機能は記憶や 情動のみならず，脳機能全体の維持に極めて重要で あり，さらに，神経の活動等により巧みに制御され ていることがわかってきた，特に本稿ではグリア前 駆細胞の増殖 - 分化, 免度応答制御について詳述し た．現在，神経炎症の抑制・緩和に係わる抗炎症関 連分子の探索・同定が行われている.

また，グリア前駆細胞が NG2 を発現することに 注目し，ラットを対象に全身の NG2 発現を蛍光あ るいは発光シグナルを通して可視化できる遺伝子改 変動物も作出できている。こうした動物を用いるこ とで, 中枢神経系以外にも NG2 分子を発現する細 胞が複数の臓器・組織に存在すること，さらにこう した細胞どうしが類似の機能を持ち合わせているこ とも見い出されつつある.このように，全身での特 定細胞のイメージング技術と，同細胞の除去技術を 組み合わせることで，これまで知られていなかった 新しい細胞機能が今後も多く見い出されてくるもの と期待している.

謝辞本稿は, ともに研究を実施した理化学研 究所の崔 翼龍博士，田村泰久博士，大和正典博士 らとの研究を中心にまとめさせて頂いた。

利益相反＼cjkstart開示すべき利益相反はない.

\section{REFERENCES}

1) Altman J., Das G. D., J. Comp. Neurol., 124, 319-335 (1965).
2) Doetsch F., Caillé I., Lim D. A., García-Verdugo J. M., Alvarez-Buylla A., Cell, 97, 703716 (1999).

3) Eriksson P. S., Perfilieva E., Björk-Eriksson T., Alborn A.-M., Nordborg C., Peterson D. A., Gage F. H., Nat. Med., 4, 1313-1317 (1998).

4) Hattori T., Hamada S., Masaki T., Kushima R., Ohmura M., Kataoka Y., Ikehara Y., Kita M., Magami Y., Biomed. Res., 10, 355-363 (1989) .

5) Tamura Y., Takahashi K., Takata K., Eguchi A., Yamato M., Kume S., Nakano M., Watanabe Y., Kataoka Y., J. Neurosci., 36, 8123-8131 (2016).

6) Nakano M., Tamura Y., Yamato M., Kume S., Eguchi A., Takata K., Watanabe Y., Kataoka Y., Sci. Rep., 7, 42041 (2017).

7) Kataoka Y., Tamura Y., Takamori Y., Cui Y., Yamada H., Med. Mol. Morphol., 39, 2832 (2006).

8) Tamura Y., Takata K., Eguchi A., Kataoka Y., Sci. Rep., 8, 393 (2018).

9) Imayoshi I., Sakamoto M., Ohtsuka T., Takao K., Miyakawa T., Yamaguchi M., Mori K., Ikeda T., Itohara S., Kageyama R., Nat. Neurosci., 11, 1153-1161 (2008).

10) Aizawa K., Ageyama N., Yokoyama C., Hisatsune T., Exp. Anim., 58, 403-407 (2009) .

11) Cameron H. A., Gould E., Neuroscience, 61, 203-209 (1994).

12) Czéh B., Michaelis T., Watanabe T., Frahm J., de Biurrun G., van Kampen M., Bartolomucci A., Fuchs E., Proc. Natl. Acad. Sci. USA, 98, 12796-12801 (2001).

13) Malberg J. E., Duman R. S., Neuropsychopharmacology, 28, 1562-1571 (2003) .

14) Snyder J. S., Soumier A., Brewer M., Pickel J., Nature, 476, 458-461 (2011).

15) Kataoka Y., Ikehara Y., Hattori T., J. Anat., 188, 375-381 (1996).

16) Tamura Y., Kataoka Y., Cui Y., Yamada H., Neurosci. Res., 50, 129-133 (2004).

17) Dawson M. R., Polito A., Levine J. M., Reynolds R., Mol. Cell. Neurosci., 24, 476-488 (2003).

18) Tamura Y., Kataoka Y., Cui Y., Takamori Y., Watanabe Y., Yamada H., Eur. J. Neu- 
rosci., 25, 3489-3498 (2007).

19) Tamura Y., Kataoka Y., Cui Y., Takamori Y., Watanabe Y., Yamada H., Neuroscience, 148, 535-540 (2007).

20) Tamura Y., Eguchi A., Jin G., Sami M., Kataoka Y., J. Cereb. Blood Flow Metab., 32, 1879-1887 (2012).

21) Guo Z., Zhang L., Wu Z., Chen Y., Wang F., Chen G., Cell Stem Cell, 14, 188-202 (2014).

22) Torper O., Ottosson D. R., Pereira M., Lau S., Cardoso T., Grealich S., Parmar M., Cell Rep., 12, 474-481 (2015).

23) Bergles D. E., Roberts J. D., Somogyi P., Jahr C. E., Nature, 405, 187-191 (2000).

24) Lin S., Bergles D. E., Nat. Neurosci., 7, 24-32 (2004).

25) Birey F., Kloc M., Chavali M., Hussein I., Wilson M., Christoffel D. J., Chen T., Frohman M. A., Robinson J. K., Russo S. J., Maffei A., Aguirre A., Neuron, 88, 941-956 (2015).

26) Djogo T., Robins S. C., Schneider S., Kryzskaya D., Liu X., Mingay A., Gillon C. J., Kim J. H., Storch K. F., Boehm U., Bourque C. W., Stroh T., Dimou L., Kokoeva M. V., Cell Metab., 23, 797-810 (2016).

27) Cui Y., Takashima T., Takashima-Hirano M., Wada Y., Shukuri M., Tamura Y., Doi
H., Onoe H., Kataoka Y., Watanabe Y., J. Nucl. Med., 50, 1904-1911 (2009).

28) Cui Y., Toyoda H., Sako T., Onoe K., Hayashinaka E., Wada Y., Yokoyama C. Onoe H., Kataoka Y., Watanabe Y., NeuroImage, 108, 17-22 (2015).

29) Nakatomi Y., Mizuno K., Ishii A., Wada Y., Tanaka M., Tazawa S., Onoe K., Fukuda S., Kawabe J., Takahashi K., Kataoka Y., Shiomi S., Yamaguti K., Inaba M., Kuratsune H., Watanabe Y., J. Nucl. Med., 55, 945-950 (2014).

30) Yamato M., Tamura Y., Eguchi A., Kume S., Miyashige Y., Nakano M., Watanabe Y., Kataoka Y., PLOS ONE, 9, e90950 (2014).

31) Katafuchi T., Kondo T., Take S., Yoshimura M., Eur. J. Neurosci., 22, 2817-2826 (2005).

32) Graeber M. B., Li W., Rodriguez M. L., FEBS Lett., 585, 3798-3805 (2011).

33) Liddelow S. A., Guttenplan K. A., Clarke L. E., Bennett F. C., Bohlen C. J., Schirmer L., Bennett M. L., Münch A. E., Chung W. S., Peterson T. C., Wilton D. K., Frouin A., Napier B. A., Panicker N., Kumar M., Buckwalter M. S., Rowitch D. H., Dawson V. L., Dawson T. M., Stevens B., Barres B. A., Nature, 541, 481-487 (2017). 